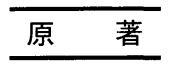

\title{
MRSA 敗血症の背景因子と治療成績の検討
}

\author{
レシャード医院1)，松江赤十字病院呼吸器科 ${ }^{2)}$, 検査科 ${ }^{3)}$ \\ カレッド・レシャード1) 田中 文啓 ${ }^{2)}$ 関根隆 ${ }^{2)}$ \\ 前迫 直久 ${ }^{3)}$ 岡 喜之介 ${ }^{3)}$ 益井加世子3) 狩野 京子 ${ }^{3)}$ \\ (平成 5 年 8 月 9 日受付) \\ (平成 5 年 10 月 8 日受理)
}

Key words: MRSA septicemia, IVH catheter infection

\begin{abstract}
要旨
1983 1991年に94例の黄色ブドウ球菌による敗血症を経験し，MSSA 48例と MRSA 46症例の背景因 子や治療成績に関して報告した。両群間の年齢には差はなく, 何れの群に括いても60歳以上の高齢者が 多く, 基礎疾患として悪性新生物, 脳血管障害, 血液疾患が多く, 免疫能低下状態にあった。感染進入 部位としては血管内操作特にIVH カテーテルによるものが大半で, 呼吸器感染症もそれに次ぐ要素で あった. MRSA 感染症の背景因子としては菌検出以前に使用されていた抗生剤の寛容が重要で, MSSA 症例の $41 \%$, MRSA の $91.3 \%$ に使用され, とくに第三世代のセフェム系抗生剤がその大部分を占め, 使 用期間扣よび種類も MSSA 群に比して多かった。治療成績では, MSSA の治癒率は $52.1 \%$ に比して, MRSA のそれは $26.1 \%$ 有意に低かった. 以上のことから, MRSA 感染症の背景因子として抗生剂の使 用頻度, 種類, 期間などが重要であり, 日常臨床の場に拉いてその使用を慎重且つ適切に行うべきであ ると強調した。
\end{abstract}

\section{序文}

近年, 医療の進歩により感染症は大きく変遷し, 悪性腫瘍，自己免疫疾患等による compromised hostで平素無害と思われていたグラム陰性桿菌 による感染症が多くなり，それに対する強力な抗 生剂が開発, 使用されるようになってさた。一方, 強力な抗生剤の使用により黄色ブドウ球菌による 感染症も増加し，特にメチシリンを初め多剂耐性 菌株による院内感染が問題となっている。そこで, 黄色ブドウ球菌, 特にメチシリン耐性黄色ブドウ 球菌による感染症として菌血症を取り上げその背 景因子や治療成績を中心に検討したので報告す る.

\section{材料と方法}

対象となった症例は1983年 1 月から1991年12月

別刷請求先：（兵427）静岡県島田市元島田9311-10 レシャード医院 カレッド・レシャード
までに当院において血液培養で黄色ブドウ球菌が 検出された94例である。これらの症例で,メチシ リン感受性菌例（以下 MSSA）は48例でメチシリ ン耐性ブドウ球菌(以下 MRSA)は46例であった。 使用された培地は, ロシュ社コロンビアボトル(好 気性用), B-D 社 SPB ボトル（嫌気性用）で, 分 離された菌株についてメチシリンの 1 濃度デスク による感受性検査を行った。

これらの症例をMSSA と MRSA群に分けて その背景因子としては; 各群の年齢, 基礎疾患, 菌の進入路と思われる初感染病巣そして過去に使 用された抗生剤の種類（第一～二世代セフェム系 薬剤と第三世代セフェム系抗生剂別）を対象とし て検討した。

有意差検定としては Kaplan-Meyer 法を使用 した。 
Fig. 1 Age distribution of S. aureus positive blood culture cases

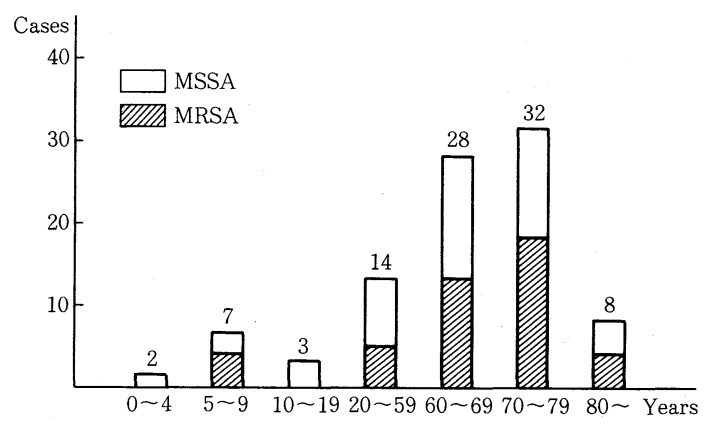

Table 1 Major underlying diseases of $S$. aureus positive blood culture (Cases)

\begin{tabular}{lcc}
\hline \multicolumn{1}{c}{ Under lying diseases } & MSSA & MRSA \\
\hline Malignant tumors & 15 & 9 \\
\hline Hematologic disorders & 6 & 7 \\
\hline Brain disorders & 6 & 7 \\
\hline Cardiac disorders & 4 & 5 \\
\hline Diabetis mellitus & 4 & 4 \\
\hline Operation \& Trauma & 1 & 3 \\
\hline Hepatic disorders & 4 & 5 \\
\hline Burns & 1 & 1 \\
\hline Others & 5 & 5 \\
\hline None & 2 & 0 \\
\hline
\end{tabular}

\section{成 績}

当検討に拈いて，1983～1985年の 3 年間に行っ た血液培養では 1 例の MRSA るみれなかっ た.また，1986～1991年間に経験された症例のう ち MSSAの検出されたものは16例, MRSA は46 例であった。 その年齢は 1 ～90歳（平均 58.8 歳） で, 60〜69と70〜79歳代にピークがみられた。 MSSA 打よび MRSA 各群の平均年齢は56.9歳, 58.4歳でその間に有意差はみられなかった（Fig. 1).これらの症例のうち 4 例に混合感染が認めら れ, その起炎菌は緑膿菌 2 例, Klebsiella pneumoniae, 大腸菌が各 1 例であった。

各群の基礎疾患を検討したところ, Table 1 の ように悪性腫瘍は MSSA 群では15例 (31.3\%), MRSA 群 9 例 (25\%) であり, 有意差検定では差
Table 2 Site of infection before isolation of $S$. aureus from blood culture (Cases)

\begin{tabular}{lcc}
\hline \multicolumn{1}{c}{ Site of infection } & MSSA & MRSA \\
\hline Intravenous catheter & 14 & 17 \\
\hline Respiratory tract & 13 & 11 \\
\hline Liver \& bile tract & 5 & 5 \\
\hline Pericardial infection & 5 & 7 \\
\hline Operation or decubitus wound & 4 & 3 \\
\hline Gento-urinary tract & 1 & 3 \\
\hline \multicolumn{1}{c}{ Others } & 6 & 0 \\
\hline
\end{tabular}

Table 3 Survival and clinical background of $S$. aureus positive blood culture (\%)

\begin{tabular}{ccccc}
\hline \multirow{2}{*}{ FACTORS } & \multirow{2}{*}{ MSSA } & \multicolumn{2}{c}{ MRSA } \\
\cline { 2 - 5 } & & & $\begin{array}{c}\text { Survived } \\
\text { cases }\end{array}$ & $\begin{array}{c}\text { Dead } \\
\text { cases }\end{array}$ \\
\hline \multirow{3}{*}{ WBC } & $\sim 9,999$ & 35.5 & 13.3 & 9.7 \\
\cline { 2 - 5 } & $10,000 \sim 20,000$ & 47.9 & 73.4 & 54.9 \\
\cline { 2 - 5 } & $20,000 \sim$ & 16.6 & 13.3 & 35.4 \\
\hline \multirow{3}{*}{ CRP } & $\sim 9$ & 39.5 & 26.7 & 12.9 \\
\cline { 2 - 5 } & $10 \sim 20$ & 27.2 & 46.6 & 32.2 \\
\hline \multirow{3}{*}{ ESR } & $\sim 20$ & 33.3 & 26.7 & 54.9 \\
\cline { 2 - 5 } & $50 \sim 100$ & 31.5 & 40.0 & 25.8 \\
\cline { 2 - 5 } & $100 \sim$ & 23.3 & 20.0 & 9.7 \\
\hline \multirow{2}{*}{ Fever } & $38^{\circ} \mathrm{C} \sim 39^{\circ} \mathrm{C}$ & 33.3 & 20.0 & 25.8 \\
\cline { 2 - 5 } & $39^{\circ} \mathrm{C} \sim$ & 67.7 & 80.0 & 74.2 \\
\hline
\end{tabular}

はみられなかった。血液疾患として白血病や悪性 リンパ腫などはそれぞれの群で 6 例と 7 例であり ほぼ同じ值となっている。その他の疾患として, 脳血管障害, 心疾患や糖尿病などの疾患について も有意差は認められなかった。

一方, 敗血症の直接の原因と考学られる菌の進 入路として IVH, 人工透析やIAPB などのカテー テルの血管内操作が最も多く, 各群の14例と17例 であり，その間にも有意の差はなかった。また， 呼吸器感染症が誘因と考えられたものはMSSA 群の初感染巣として13例, MRSA 群は11例であり その間には有意差はなかった（Table 2). 
臨床的背景として MRSA 群において, 白血球 やCRP の高值の症例は多かったのに対して, 赤 沈値の低いものが多く, DIC 等の合併の可能性が 示唆された。一方，発熱に拈いては有意差は認め られなかった。な扮，この傾向はMRSA 群の生存 例と死亡例共に同様に認められた（Table 3).

MRSA 感染症の発見以前の 4 週間またはそれ 以前からこの期間までに続けて使用された抗生剤 を各群別に検討したところ, MSSA 群の $39.5 \%$ と MRSA 群の $91.3 \%$ に抗菌剂は使用され, その比率 はMRSA 群が極端に多かった。一方, 使用された 抗菌剤の種類を見たところ，一～二世代セフェム 系の薬剤の比率は各々の群で $76.2 \%, 35.8 \%$ であ り, MRSA 群に括いて第三世代のセフェム系抗生 剤の使用が圧倒的に多いことが判った。他方で, 一症例に使用された薬剤はMSSA 群では平均 3.1種類であったのに対して, MRSA 群では平均

Table 4 Administrated antibiotics before isolation of S. aureus from blood culture (\%)

\begin{tabular}{lcc}
\hline \multicolumn{1}{c}{ Administrated antibiotics } & MSSA & MRSA \\
\hline Non-administrated & 60.5 & 8.7 \\
\hline Administrated & 39.5 & 91.3 \\
\cline { 2 - 3 } $\begin{array}{c}\text { Drugs/case } \\
\text { Days/case }\end{array}$ & 3.1 & 3.6 \\
\hline 1 2nd generation cephems & 76.6 & 35.6 \\
\hline 3rd generation cephems & 23.8 & 35.8 \\
\hline
\end{tabular}

3.6種であり, またその使用期間についてもそれぞ れ20.6日，35.6日と各群間に有意差が認められた (Table 4).

起炎菌検出前に使用された抗生剂を種類別で検 討したところ，゚゚ニシリン系のものはMSSA の 症例では 3 例, MRSA 症例では11例であり, それ ぞれの使用日々 7 日，12日であった. MRSA が検 出された症例において第三世代セフェム系薬剤, アミノグリコシド系など各系統の抗生剂が幅広く 使われていたことが判明し，またその使用日数も MSSA 群より長期であることは先述した通りで ある (Table 5).

これらの症例のうち MRSA による敗血症の治 療成績は Table 6 に示している. 抗菌剤として使 用されたものではイミペネム (IPM) やミノサイ クリン (MINO) が多く, 治癒率はバンコマイシ ン $(\mathrm{VCM})$ が最も良好であったが，他の抗生剤の それは $30 \%$ 前後と同程度であった。しかし，汪と んどの症例に扣いてこれらの薬剤は他剤とともに 使用されているため単一薬剂としての有効率の評 価は困難である。

以上の94例の敗血症例の予後について検討した

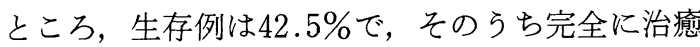
した症例は $39.4 \%$ ，キャリアとして退院した症例 は 3 例 $(3.2 \%)$ であり，57.5\%の症例が死亡され た。この数值を先述の各群別でみると; MSSA 群

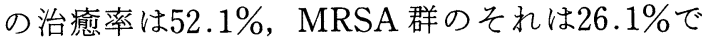

Table 5 Administrated antibiotics before isolation of $S$. aureus from blood culture

\begin{tabular}{|c|c|c|c|c|c|c|}
\hline \multirow[b]{2}{*}{ Antibiotics } & \multicolumn{3}{|c|}{ MSSA } & \multicolumn{3}{|c|}{ MRSA } \\
\hline & Cases & $\begin{array}{l}\text { The average } \\
\text { adm. days }\end{array}$ & $\begin{array}{l}\text { Survival } \\
\text { rate }\end{array}$ & Cases & $\begin{array}{l}\text { The average } \\
\text { adm. days }\end{array}$ & $\begin{array}{c}\text { Survival } \\
\text { rate }\end{array}$ \\
\hline Penicillin der. & 3 & 7 & \multirow{9}{*}{52.1} & 11 & 12 & \multirow{9}{*}{26.1} \\
\hline 1st generation cephems & 5 & 10 & & 7 & 14 & \\
\hline 2nd generation cephems & 1 & 14 & & 12 & 16 & \\
\hline 3rd generation cephems & 5 & 20 & & 61 & 21.5 & \\
\hline Aminoglucosides & & & & 6 & 17 & \\
\hline ST combination & & & & 3 & 14 & \\
\hline Fosfomycin & & & & 7 & 11 & \\
\hline Erythromycin & & & & 1 & 10 & \\
\hline Others & 5 & 11 & & 8 & 15 & \\
\hline
\end{tabular}


Table 6 Treatment and prognosis of bacteremia due to MRSA (Cases)

\begin{tabular}{ccccccc}
\hline Antibiotics & Cases & Combination & Survived & Carrier & Dead & Cure rate (\%) \\
\hline IPM & 13 & $\begin{array}{l}2 \text { drugs } \\
3 \text { drugs }\end{array}$ & $\begin{array}{c}1 \\
3\end{array}$ & & 2 & 30.7 \\
\hline S/C & 3 & $\begin{array}{l}1 \text { drug } \\
3 \text { drugs }\end{array}$ & 1 & & 1 & 33.3 \\
\hline FOM & 4 & $\begin{array}{l}2 \text { drugs } \\
3 \text { drugs }\end{array}$ & 1 & & 2 & 25.0 \\
\hline MINO & 8 & $\begin{array}{l}2 \text { drugs } \\
3 \text { drugs }\end{array}$ & 2 & 1 & 2 & 37.5 \\
\hline ABK & 6 & $\begin{array}{l}2 \text { drugs } \\
3 \text { drugs }\end{array}$ & 2 & & 4 & 33.3 \\
\hline VCM & 6 & $\begin{array}{l}2 \text { drugs } \\
3 \text { drugs }\end{array}$ & 1 & 2 & 1 & 66.6 \\
\hline Total & 40 & & 12 & 3 & 2 & 37.5 \\
\hline No-Treatment & 6 & & & 6 & 0.0 \\
\hline
\end{tabular}

MSSA 群の約半数であった。

\section{考 察}

黄色ブドウ球菌は1980年代以降，血液培養分離 菌の第 2 に位置していることは「本邦の感染症起 炎菌の変遷とその実態把握」の研究班の調查成績 で明らかであり，また同分離菌の約半数は MRSA であることも同時に報告されている1).当院に沶 いて今回の検討期間内に検索された $3,295 の$ 血液 培養の検体の陽性率は $16.4 \%$ であり, そのらち黄 色ブドウ球菌が $38.1 \%$ と最も多く，カンジダの $30 \%$ これに次ぐ。この黄色ブドウ球菌のうち $19.7 \%$ がコアグラーゼ陰性ブドウ球菌, $15.8 \%$ が MRSA であり, 以上の研究班の研究成績に一致し た結果を得て, MRSA 敗血症は決して珍しいもの ではないことが判明した。この MRSA 敗血症の 増加傾向は年々目立つょうになり，千葉ら 1986年に数\%であった MRSA の検出率は1989年 には約 $50 \%$ に達していることを指摘している。ま た, Mylotte ら ${ }^{3)}$ の報告では血液検体に打ける10万 人に対するブドウ球菌の検出率は 1977 年には 16.1 であったのに対して1988年では20，1985年には 28.5 と増加傾向にある。

MRSA 敗血症の背景因子としては，患者の年 齢, 全身状態, 基礎疾患, 初感染部位などの他に 過去に使用された抗生剂の寛容が示唆されてい る4) 6). Cafferkey ら ${ }^{7)}$ はブドウ球菌による敗血症 患者の年齢は60歳代以降に有意に多いことを指摘
し，高齢がその背景因子として憂慮すべきである と報告している。一方，基礎疾患がその発生を左 右することは岡ら ${ }^{8)}$ の経験した93例全員にみら れ，特に悪性腫瘍，脳血管障害が全体の $58 \%$ を占 めていた。当検討に拈いても同様に悪性疾患，脳 血管障害や血液疾患が全体の $52 \%$ 占め，基礎疾 患を有さない症例はなく，すべての症例が何らか の免疫能低下状態にあったことが示唆された。初 感染部位としては血管内カテーテルや透析カテー テルが誘因となったものはMSSA および MRSAの症例にともに多くみられ, 呼吸器感染症 がこれに次ぐ原因と思われた。 加藤ら ${ }^{9)}$ の成績で は肺炎が約半数の症例に先行し, 岡ら ${ }^{8)}$ 症例で も高率にみられ，な扮かつその死亡率が最も高い ことを指摘している.

MRSA 菌血症の発生の背景因子として過去に 使用された抗生剤との関連が指摘されているが, 明確なデータを示した論文は少なく, Cafferkey ら7は66例中52例に血液から菌が検出された時点 ではセフェム系, ペニシリン系やアミノグリコシ ド系抗生剤が使用されていたことを報告し，何ら かの因果関係があるのではないかと示唆してい る. 本研究では, MSSA と MRSA の群間には使 用された抗生剤の種類, 使用頻度, 使用期間など 何れの項目においても, 有意差が認められ, 過去 4 週間に使用された薬剤の影響は大であり, 特に 第三世代セフェム系抗生剂の使用頻度が高いほど 
その発生率も高くなるように思われた。これは臨 床の場に扣いて軽度の感染症の時でも最初から 種々の抗生剤(第三世代のセフェム系薬剤を含む) が使用されている現状によるものであろう。嶋田 ら ${ }^{10)}$ 榴置尿路カテーテル挿入患者に抢いては細 菌尿が $1 \times 10^{5} \mathrm{CFU} / \mathrm{ml}$ であっても, 無症候性であ れば抗菌剂の全身投与は不要であると指摘してい る。一方では, 粉川ら ${ }^{1)}$ “一般外来診療に拈ける 感冒様症状に対する抗菌剂投与の妥当性ならびに 有用性”之題した研究報告をし，その大半はウイ ルス性感染であり, CRP 陽性患者は $33 \%$ に過ぎな いにも関わらず抗生剤の投与が有効であったとし た上で，その早期投与を推奨している。このよう な傾向は一般臨床の場に扔いて度々散見されるこ とから，今後はMRSA を含む多剂耐性菌による 感染やその背景因子を考慮し, 臨床の場で抗生剂 の使用および選択を慎重に行らべきである。

MRSA 敗血症の治療成績については様々な報 告はあるが12) 14), その治癒率は決して高いもので はなく, 30〜 70\%とされ, やはり治療成績を向上 するよりもその予防に努めるべきである.

以上，黄色ブドウ球菌による敗血症とくに MRSA によるものの背景因子について検討し報 告した.

1）島田 肇, 岡 慎一, 鈴木宏男: 黄色ブドゥ球菌 敗血症の研究. 第 1 報。メチンリン・セフェム耐 性黄色ブドゥ球菌敗血症について. 感染症誌, 59 : 459-463, 1985.

2) 千葉直彦, 三木礼子, 平岡秀子, 鶴田咲子: MRSA 敗血症の臨床的検討. 山梨中病年報, $17: 13,1990$.

3) Mylotte, J.M., McDermott, C. \& Spooner, J.A. : Prospective study of 114 consective episodes of Staphylococcus bacteremia. Rev. Infect. Dis., 9: 891-907, 1987.

4）青木洋三, 谷村 弘, 落合 実, 角田卓也：院内
感染の現況と対策. 化学療法の領域, $7: 265-274$, 1991.

5）横田 健：メチシリン・セフェム耐性黄色ブドウ 球菌とコアグラーゼ陰性ブドウ球菌遺伝的耐性株 の耐性機構と対策. Chemotherapy, 36:873-884, 1988.

6）長尾二郎，炭山嘉信：TPN 施行時に見られたカ テーテル敗血症について. New Diet Therapy, 7 : 46-50, 1991.

7) Cafferkey, M.T., Hone, R. \& Keane, C.T. : Sources and outcome for methicillin-resistant Staphylococcus aureus bacteremia. J. Hosp. Infect., $11: 136-143,1988$.

8）岡 慎一, 浦山京子, 稲松孝思, 島田 肇：黄色 ブドウ球菌敗血症の研究．第 2 報。高齢者に拉け る黄色ブドウ球菌敗血症 93 例の臨床的検討. 感染 症誌, 60 : 602-607, 1986.

9）加藤研一, 奥田和之, 上殿泰成, 相尾信昭, 武山 直志，田中孝也：菌血症ことに多剂耐性黄色ブド ウ球菌感染症に関する検討. ICU と CCU, $14: 239$ $-245,1990$.

10）嶋田甚五郎：院性感染症に必要な抗菌薬. 治療学, 5: 113-114, 1990.

11）粉川皓年：一般が外来診療に括ける感冒症状様症 状に対する抗菌剤投与の妥当性ならびに有用性に ついて. Progress in Med., 6: 121-124, 1992.

12) Ringberg, H., Thoren, A. \& Bredberg, A.: Evaluation of coagulase-negative Staphylococci in blood cultures. A prospective clinical and microbiological study. Scand. J. Infect. Dis., 23 : 315-323, 1991.

13) Overturf, G.D., Sherman, M.P. \& Scheifle, D. W.: Neonatal necrotizing entrocoloitis associated with toxin-producing methicillinresistant Staphylococcus aureus. Ped. Infect. Dis. J., 9 : 88-91, 1990.

14) Marcon, M.J., Nahata, M.C., Powell, D.A. \& Lisby-Sutch, S.M. : $\quad \beta$-Lactam susceptibility of coagulase-negative Staphylococci causing catheter sepsis in pediatric patients. Diagn. Microbiol. Infect. Dis., 13 : 9-15, 1990. 
A Prospective Study of Septic Episodes due to Staphylococcus aureus and the Background of the Patients

Khaled RESHAD, Fumihiro TANAKA, Takashi SEKINE, Naohisa MAESAKO, Kayoko MASUI, Kinosuke OKA \& Kyoko KARINO

Respiratory Diseases Department, Matsue Red Cross Hospoital

From January 1983 to December 1991, 94 cases of Staphylococcus aureus septicemia were identified at Matsue Red Cross Hospital and were evaluated. Methicillin-resistant Staphylococci aureus counted $49 \%$. Seventy two percent of the patients were 60 years or over in age. Intravascular catheters were the most common foci $(33 \%)$, respiratory infections in $25 \%$ and so on. Administration of antibiotics before isolation of Staphylococcus aureus were thought to be the most significant factor in producing the methicillin-resistant septicemia, used in $41 \%$ of MSSA and $91.3 \%$ of MRSA cases. Especially, the trend of unproper usage of the 3 rd generation cephems deravative antibiotics had a major role in producing multi-drug resistant bacteria. No significance was seen in the clinical background, underlying diseases, primary site of infection in between the two groups of methicillin resistant and sensitive cases. Mortality due to septicemia was $47.9 \%$ in the MSSA group of patients, while it was much higher in cases of MRSA (73.9\%).

In conclusion, as the administration of antibiotics even in non-infectious episodes is common in daily clinical activities in some out-patient clinics, the indications should be restricted, in order to prevent the further MRSA infections. 